Check for updates

Cite this: RSC Adv., 2019, 9, 21519

Received 15th May 2019

Accepted 4th July 2019

DOI: $10.1039 / c 9 r a 03673 c$

rsc.li/rsc-advances

\section{Expeditious synthesis and preliminary antimicrobial activity of deflazacort and its precursors $\dagger$}

\author{
Anna Esposito, (D) a Eliana De Gregorio, (ID b Maria De Fenza, (D) a Daniele D'Alonzo, \\ Anil Satawanic and Annalisa Guaragna (D) *a
}

The synthesis of deflazacort (DFZ) and a preliminary evaluation of its microbial activity against the human pathogens Acinetobacter baumannii and Staphylococcus aureus is herein reported. While DFZ is inactive, one of its synthetic precursors showed a strong antibacterial activity against both Gram-negative and -positive bacteria.

\section{Introduction}

Mineralocorticoids (MCs) and glucocorticoids (GCs) belong to the group of corticosteroids (hormones with 21 carbon atoms) and are basically classified based on their preferential biological activity, depending on their involvement in the balancing of fluids and electrolytes or in the regulation of carbohydrate metabolism, respectively. ${ }^{1}$

The immunosuppressive and anti-inflammatory properties of GCs, mainly due to inhibition of specific leucocyte functions, are well-established. ${ }^{2}$ The first efforts in this field led to the synthesis of novel corticosteroids such as prednisolone (1, Fig. 1) and prednisone (2, Fig. 1), which were endowed with a higher anti-inflammatory potency than natural cortisone, along with lower undesired effects. Inspired by these results, a variety of other corticosteroids with different therapeutic applications were synthetized, including fluorinated GCs betamethasone (3) and dexamethasone (4).

The search of novel anti-inflammatory drugs characterized by high efficacy and good tolerability in each age group, led to identification of deflazacort (5), a heterocyclic corticosteroid, acting as a new anti-inflammatory/immunosuppressive agent. Indeed, $\mathbf{5}$ is endowed with a lower interference with carbohydrate and phosphocalcium metabolism compared with previous-generation corticosteroids and it is therefore able to produce less serious metabolic events. ${ }^{3,4}$ DFZ, the oxazolinederivative prodrug of prednisolone, ${ }^{5}$ after oral administration is rapidly converted into the active metabolite, 21-desacetyldeflazacort (6, Fig. 2), by cellular esterases. ${ }^{6}$

\footnotetext{
${ }^{a}$ Department of Chemical Sciences, University of Napoli Federico II, Via Cintia, 80126 Napoli, Italy. E-mail: annalisa.guaragna@unina.it

${ }^{b}$ Department of Molecular Medicine and Medical Biotechnologies, Via S. Pansini, 5, 80131 Napoli, Italy

'Symbiotec Pharmalab Pvt Ltd, Pithampur, Indore, India

$\dagger$ Electronic supplementary information (ESI) available: Experimental procedures, copies of ${ }^{1} \mathrm{H},{ }^{13} \mathrm{C}$ and ${ }^{1} \mathrm{H}-{ }^{1} \mathrm{H}-\mathrm{COSY}$ NMR and LC-MS spectra of all compounds and biological details. See DOI: 10.1039/c9ra03673c
}

To exert its pharmacological effect, DFZ acts as corticosteroid hormone receptor agonist, exploiting the high binding affinity for tissue glucocorticoid receptors. ${ }^{7}$ Very recently, DFZ was approved ${ }^{8}$ by the FDA (trade name: Emflaza) for its use in treatment of Duchenne Muscular Dystrophy (DMD), a genetic disorder that affects $1 / 3600$ infants worldwide. However, the precise mechanism by which DFZ exerts its therapeutic effect in patients with DMD is still unknown.

Even though the anti-inflammatory and immunosuppressive activity ${ }^{4}$ of DFZ is well-known, there are no reports to the best of our knowledge about its direct action on bacterial infections. In this context, our ongoing interest into the synthesis of bioactive compounds ${ }^{9}$ prompted us to develop a new synthetic protocol for the preparation of DFZ. In addition, the evaluation of the antimicrobial potential of DFZ as well as of its steroidal synthetic precursors against Acinetobacter baumannii and Staphylococcus aureus was assessed by in vitro assays.
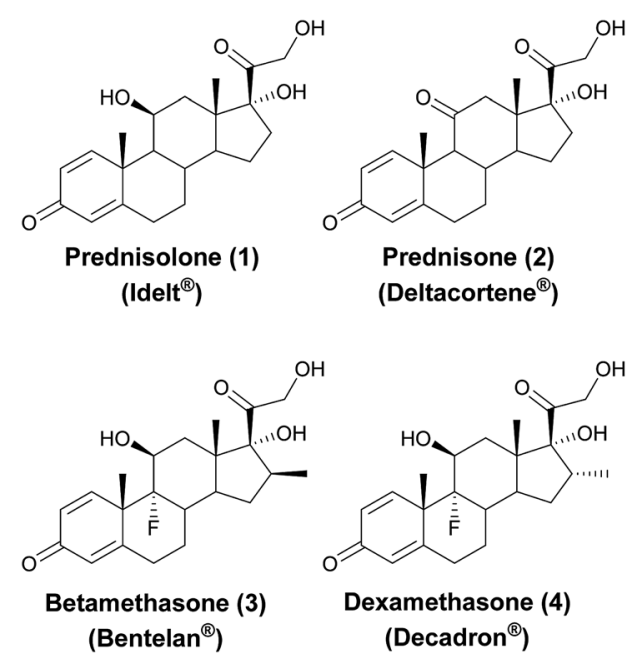

Fig. 1 Anti-inflammatory man-made glucocorticoids. 


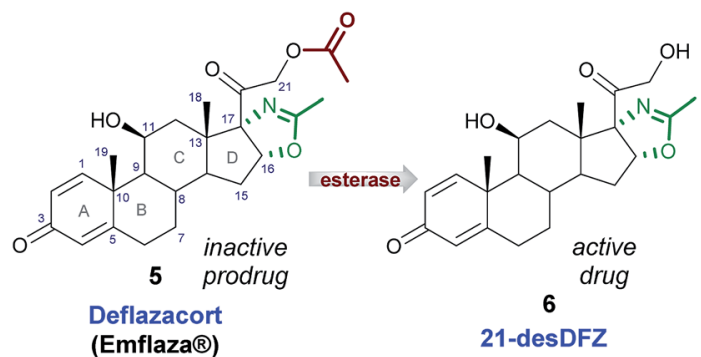

Fig. 2 Deflazacort (5) and its active metabolite 21-desDFZ (6).

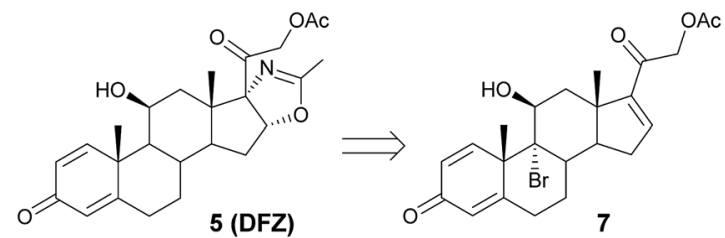

Scheme 1 Retrosynthetic pathway to DFZ synthesis.

\section{Results and discussion}

Our synthesis started from 9-bromotriene acetate 7 (Scheme 1), readily obtained from the commercially available tetraene acetate $^{\mathbf{1 0}}$ (3TR), an industrial key intermediate already used for the synthesis of currently marketed bioactive glucocorticoid drugs. ${ }^{11}$

The use of 7 allowed us to have the proper functionalization at C21 position, as required by the DFZ structure, avoiding the installation of the acetylated 21-hydroxyl function in a late stage of the synthesis, as commonly reported for oxazolinecontaining steroids. ${ }^{12}$

At first, double bond epoxidation at C16-C17 positions of the starting material was studied, to be then further elaborated for conversion into the oxazoline moiety of 5 . The epoxidation reaction was attempted on both 7 and its debrominated derivative 8 , in turn obtained by treatment of 7 with $\mathrm{Bu}_{3} \mathrm{SnH}$ and AIBN in refluxing THF (93-98\% yield) (Table 1).

Nearly neutral or acidic conditions were tested, since alkaline double bond epoxidation was hampered by the presence of the acetyl group at $\mathrm{C} 21$ position. The best results were obtained by treatment of 7 or 8 with $m$ CPBA in refluxing DCM (entries 1 and 4, Table 1), obtaining in both cases the desired $\alpha$-epoxides 9 and 10 in $47 \%$ and $40 \%$ yield. On the contrary, the use of in situ generated TFDO (Oxone/ $\mathrm{NaHCO}_{3} /$ aq. $\mathrm{Na}_{2}$ EDTA) (entries 2 and 5 , Table 1) demonstrated to be unsuited, as it led to the formation of undesired epoxides $\mathbf{1 1}$ and $\mathbf{1 2}$ (from 7 and 8, respectively). The use of bicarbonate-catalyzed epoxidation with aqueous hydrogen peroxide, ${ }^{13}$ at near neutral $\mathrm{pH}$, afforded only a minor amount of 9 (13\%, from 7$)$, while epoxide 11 was isolated as the main product (59\%) (entry 3, Table 1). Under the same conditions, the reaction from olefin $\mathbf{8}$ led to the recovery of totally unreacted starting material (entry 6, Table 1).

With epoxide 10 in hand, conversion of the latter into cis-17amino-16-hydroxy derivative 16 was accomplished either by a stepwise route (path a, Scheme 2) or by a one-pot procedure (path b, Scheme 2), exploiting the formation of the corresponding carboethoxy hydrazone 13. Indeed, hydrazone groupscontaining oxidosteroids are reported to be able to efficiently drive the regio- and stereoselective ring opening of neighbouring three-membered heterocycles. ${ }^{14}$ Thus, hydrazone 13 could represent a valuable intermediate to selectively introduce a vicinal amino-alcohol function in $\mathrm{C} 16$ and $\mathrm{C} 17$ positions with the desired cis-configuration.

As shown in Table 2, different reaction conditions were explored, treating $\mathbf{1 0}$ with ethyl carbazate, varying both the reaction solvent and the activating agent. In almost all cases, unsatisfactory results were obtained (entries 1-3), since only limited conversions were achieved, while the recovery of unreacted staring material was mainly found. On the other hand, when the reaction was carried out with $\mathrm{Py} \cdot \mathrm{HCl}$ in

Table 1 Epoxidation of derivatives 7 and $8^{a}$
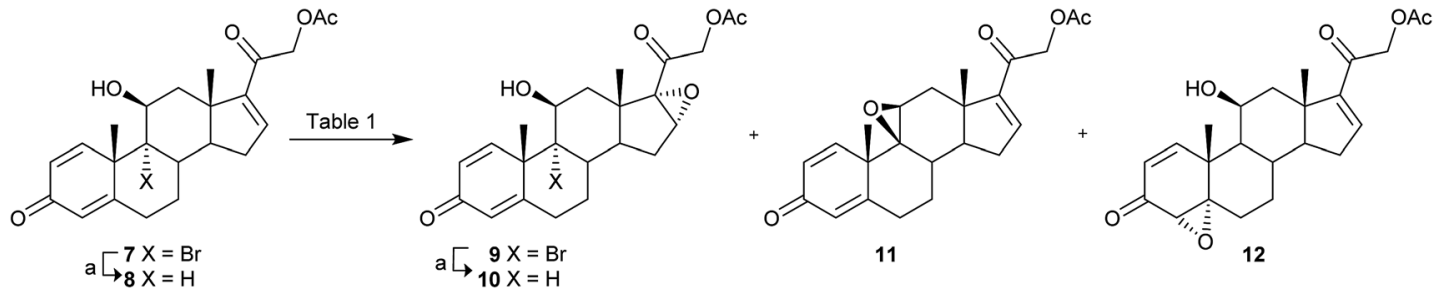

\begin{tabular}{|c|c|c|c|c|c|c|}
\hline Entry & Compd & Reacting system & Solvent & $\operatorname{Temp}\left[{ }^{\circ} \mathrm{C}\right]$ & $t[\mathrm{~h}]$ & Yield [\%] \\
\hline 1 & 7 & MCPBA & DCM & $\Delta$ & 16 & 9: 47 \\
\hline 2 & 7 & Oxone/ $\mathrm{NaHCO}_{3}$ /aq. $\mathrm{Na}_{2}$ EDTA & $\mathrm{CF}_{3} \mathrm{COCH}_{3} / \mathrm{ACN}$ & $\mathrm{rt}$ & 18 & 11: 51 \\
\hline 4 & 8 & MCPBA & DCM & $\Delta$ & 16 & 10: 40 \\
\hline 5 & 8 & Oxone/NaHCO 3 /aq. $\mathrm{Na}_{2}$ EDTA & $\mathrm{CF}_{3} \mathrm{COCH}_{3} / \mathrm{ACN}$ & $\mathrm{rt}$ & 18 & 12: 55 \\
\hline 6 & 8 & $\mathrm{H}_{2} \mathrm{O}_{2} / \mathrm{NH}_{4} \mathrm{HCO}_{3}$ & $\mathrm{ACN} / \mathrm{H}_{2} \mathrm{O}$ & $\mathrm{rt}$ & 18 & - \\
\hline
\end{tabular}

${ }^{a} \mathrm{Bu}_{3} \mathrm{SnH}$, AIBN, THF, reflux, 30', 93-98\%. 

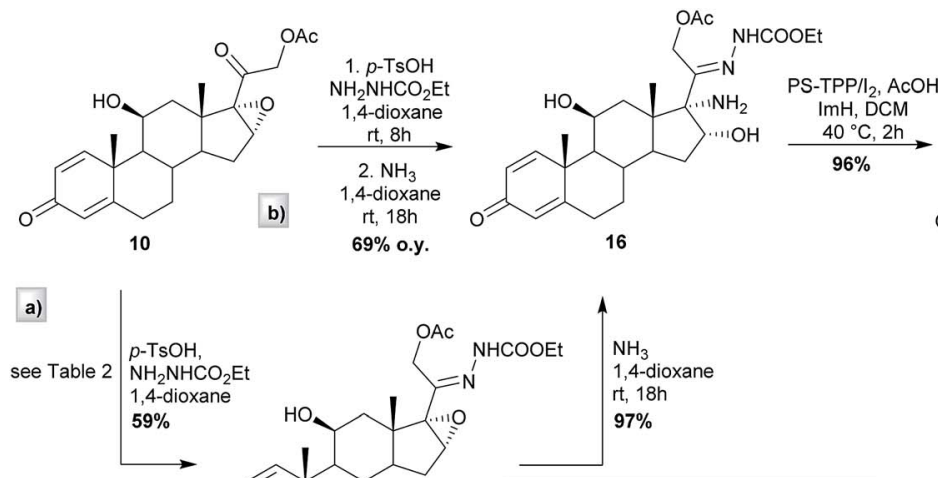

$69 \%$ o.y

16

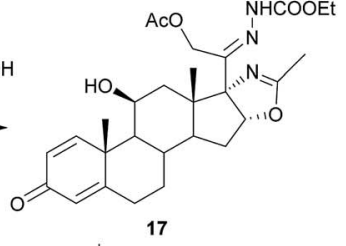

Table 2 Experimental conditions for the conversion of ketone 10 into carboethoxy hydrazone 13

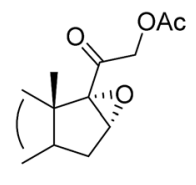

10
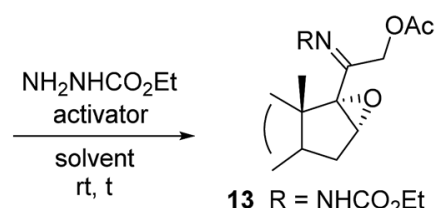

$13 \mathrm{R}=\mathrm{NHCO}_{2} \mathrm{Et}$

\begin{tabular}{lllll}
\hline Entry & $\begin{array}{l}\text { Activating } \\
\text { agent }\end{array}$ & Solvent & $t(\mathrm{~h})$ & Yield (\%) \\
\hline 1 & $\mathrm{AcOH}$ & 1,4-Dioxane & 18 & 12 \\
2 & $\mathrm{H}_{2} \mathrm{SO}_{4}$ & DMF & 16 & 20 \\
3 & $\mathrm{CSA}$ & Toluene & 16 & 16 \\
4 & Py-HCl & Pyridine & 24 & 30 \\
5 & $p-\mathrm{TsOH}$ & 1,4-Dioxane & $8 \mathrm{~h}$ & 59 \\
\hline
\end{tabular}

pyridine (entry 4), the protection of both C20 and C3 carbonyl functions occurred, affording hydrazone 14 in $30 \%$ yield. The desired C20 monoprotected derivative 13 was instead easily obtained in good yield (59\%), using ethyl carbazate and $p$-toluenesulfonic acid in anhydrous 1,4 dioxane (entry 5).

The epoxide ring opening from hydrazone 13 was then considered. Treatment of $\mathbf{1 3}$ with $\mathrm{NH}_{3}$ in dioxane afforded the desired cis-17-amino-16-hydroxy derivative 16 in 97\% yield (Scheme 2, path a). Differently from the well-known acidcatalysed epoxide ring opening carried out on similar steroid derivatives, the stereochemical outcome of the reaction under basic conditions can be rationalized assuming that $\mathrm{NH}_{3}$ deprotonates hydrazone 13, enabling epoxide ring opening to give the intermediate 15 (PM3; HyperChem ${ }^{\mathrm{TM}}$, rel 8.0.3). The latter then undergoes nucleophilic attack by ammonia from the less hindered side of ring D, leading to amino-alcohol 16. As previously mentioned, $\mathrm{C} 20$ protection and epoxide ring opening steps were also performed in a one-pot procedure (Scheme 2, path b) leading to the same results in terms of reaction times and yields.
Oxazoline ring formation from 16 was eventually studied, using the well-known polymer supported triphenylphosphine/ iodine/imidazole ${ }^{15}$ (PS-DPP/ $\left./ \mathrm{I}_{2} / \mathrm{ImH}\right)$ system as the activating agent. ${ }^{16}$ Treatment of $\mathrm{AcOH}$ with 2.0 equivalents of the previously mixed PS-DPP/ $\mathbf{I}_{2}$ followed by the addition of $\mathbf{1 6}$ and $\mathrm{ImH}$ to the reaction mixture provided, already after $2 \mathrm{~h}$ in refluxing DCM, the desired 17 in high yield (96\%) and purity. The first equivalent of PS-TPP/ $\mathrm{I}_{2}$ is needed to activate acetic acid, whereas a second equivalent of the complex promotes the hydroxyl group activation. The addition of ImH to the reaction medium ensures neutral/mild alkaline environment by trapping protons released during the course of the reaction and the amide proton abstraction, thus promoting oxazoline ring closure. It's worth noting that the only reaction by-product, i.e. the resin-bound phosphine oxide, can be easily filtered off and eventually recycled, providing the original phosphine by reduction with trichlorosilane. ${ }^{17}$

Lastly, removal of $\mathrm{C} 20$ hydrazone function ( $\mathrm{HCl} /$ acetone) on 17 smoothly provided the pure Deflazacort (5) in $72 \%$ yield.

DFZ and its synthetic precursors were evaluated in experiments aimed to determine the minimum inhibitory concentration (MIC) against Staphylococcus aureus and Acinetobacter baumannii, ${ }^{18}$ two bacterial pathogens that have become one of major causes of lifethreatening infections. A. baumannii and S. aureus were classified as critical and high priority pathogens, respectively, as they rapidly developed multi-resistance to antibiotics. ${ }^{19}$ Compounds 5 and 16 were inactive as growth inhibitors even at the high experimental concentrations $\left(1 \mathrm{mg} \mathrm{mL}{ }^{-1}\right)$, whereas compounds 13 and 17 showed only weak antimicrobial activity (Table 3). On the contrary, epoxide 10 showed inhibition at concentrations as low as $16 \mu \mathrm{g}$ $\mathrm{mL}^{-1}$ for both $S$. aureus and A. baumannii strains. Interestingly, compounds 10 and 13 also work as bactericidal agents, having minimum bactericidal concentration (MBC) values generally equal or three-fold higher than their MIC values (Table 3).

Cytotoxicity of $\mathbf{1 0}$ was assessed in vitro using hemolytic assay measuring its hemolytic activity against horse RBCs at final concentrations ranging from 1 to $512 \mu \mathrm{g} \mathrm{mL} \mathrm{m}^{-1}$. The glucocorticoid 
Table 3 MIC ( $\mathrm{mg} \mathrm{mL}^{-1}$ ) and MBC ( $\mathrm{mg} \mathrm{mL}^{-1}$ ) values of DFZ and its synthetic precursors on one reference strain of $S$. aureus and $A$. baumannii compared with MIC of some known antimicrobial agents ${ }^{a}$

\begin{tabular}{|c|c|c|c|c|}
\hline \multirow[b]{3}{*}{ Compound } & \multicolumn{4}{|c|}{ Bacteria } \\
\hline & \multicolumn{2}{|c|}{$\begin{array}{l}\text { S. aureus ATCC } \\
29213\end{array}$} & \multicolumn{2}{|c|}{$\begin{array}{l}\text { A. baumannii ATCC } \\
17978\end{array}$} \\
\hline & MIC & MBC & MIC & MBC \\
\hline 10 & 0.016 & 0.016 & 0.016 & 0.016 \\
\hline 13 & 0.375 & 1 & $>1$ & $>1$ \\
\hline 16 & $>1$ & $>1$ & $>1$ & $>1$ \\
\hline 17 & 0.75 & $>1$ & $>1$ & $>1$ \\
\hline DFZ & $>1$ & $>1$ & $>1$ & $>1$ \\
\hline Vancomycin & 0.001 & ND & ND & ND \\
\hline Methicillin & 0.0025 & ND & ND & ND \\
\hline Gentamicin & 0.0005 & ND & 0.0015 & ND \\
\hline Ampicillin & ND & ND & $>0.032$ & ND \\
\hline Amikacin & ND & ND & 0.004 & ND \\
\hline
\end{tabular}

${ }^{a}$ MIC experiments were carried out in triplicates and was determined by broth microdilution assay as previously describes $;{ }^{20} \mathrm{ND}$ : not determined.

epoxide 10 showed no hemolytic activity at concentrations of up to $128 \mu \mathrm{g} \mathrm{mL}^{-1}$, whereas was $62.8 \%$ and $78.6 \%$ at $256 \mu \mathrm{g} \mathrm{mL}{ }^{-1}$ and $512 \mu \mathrm{g} \mathrm{mL}{ }^{-1}$, respectively. ${ }^{21}$

\section{Conclusions}

In summary, we tuned up a novel and efficient synthesis of deflazacort in few steps from 9-bromotriene acetate 7 by regioand stereoselective functionalization of C16 and C17 positions. In search for antibacterial activity of DFZ and its synthetic precursors, we found that epoxide 10 displayed interesting biological properties. Further studies will be aimed to an indepth evaluation of the antimicrobial properties of $\mathbf{1 0}$, as well as the determination of the mechanism of action.

\section{Experimental}

\section{Chemical synthesis}

General methods and materials. All chemicals and solvents were purchased with the highest degree of purity (SigmaAldrich, Alfa Aesar, VWR) and used without further purification. 9-Bromotriene acetate 7 was provided by Symbiotec Pharmalab PVT. All moisture-sensitive reactions were performed under nitrogen atmosphere using oven-dried glassware. The reactions were monitored by TLC (precoated silica gel plate F254, Merck) and the products were detected by exposure to ultraviolet radiation, iodine vapor, and chromic mixture. Column chromatography: Merck Kieselgel 60 (70-230 mesh); flash chromatography: Merck Kieselgel 60 (230-400 mesh). The purity of the synthetic intermediates and the final compound was determined by CHNS analysis and was $\geq 95 \%$ in all cases. NMR spectra were recorded on NMR spectrometers operating at $400 \mathrm{MHz}$ (Bruker DRX, Bruker AVANCE) or $500 \mathrm{MHz}$ (Varian Inova), using $\mathrm{CDCl}_{3}$ solutions unless otherwise specified. Coupling constant values $(J)$ were reported in $\mathrm{Hz}$.

Synthetic procedures
1,4-Pregnadiene-9-bromo-11-hydroxy-16 $\alpha, 17 \alpha$-epoxy-3,20-dione (9). To a stirred solution of 9-bromotriene acetate 7 (1.0 g, 2.16 $\mathrm{mmol})$ in anhydrous $\mathrm{CH}_{2} \mathrm{Cl}_{2}(30 \mathrm{~mL}), m$-CPBA $(0.75 \mathrm{~g}, 4.32$ $\mathrm{mmol}$ ) was added at room temperature. The mixture was warmed to reflux and stirred for $16 \mathrm{~h}$. Then, aq. $\mathrm{NaHCO}_{3}$ was added and the mixture extracted with $\mathrm{CH}_{2} \mathrm{Cl}_{2}$; the organic layer was dried $\left(\mathrm{Na}_{2} \mathrm{SO}_{4}\right)$ and the solvent evaporated under reduced pressure. The solid residue was recrystallized from AcOEt to give the final compound $9(0.49 \mathrm{~g}, 47 \%$ yield $)$ as a white solid. ${ }^{1} \mathrm{H}$ NMR (400 MHz): $\delta 1.41$ (s, 3H), 1.48-1.55 (m, 1H), $1.70(\mathrm{~s}, 3 \mathrm{H})$, 1.71-1.82 (m, 2H), 1.94-2.05 (m, 3H), 2.15 (s, 3H), 2.16-2.25 (m, $1 \mathrm{H}), 2.36-2.49(\mathrm{~m}, 2 \mathrm{H}), 2.55-2.68(\mathrm{~m}, 1 \mathrm{H}), 3.85(\mathrm{~s}, 1 \mathrm{H}), 4.59(\mathrm{~d}, J$ $=13.4,1 \mathrm{H}), 4.67(\mathrm{~d}, J=13.4,1 \mathrm{H}), 4.76(\mathrm{bs}, 1 \mathrm{H}), 6.07(\mathrm{bs}, 1 \mathrm{H})$, $6.32(\mathrm{~d}, J=10.1,1 \mathrm{H}), 7.21(\mathrm{~d}, J=10.1,1 \mathrm{H}) .{ }^{13} \mathrm{C}$ NMR $(100 \mathrm{MHz})$ : 18.3, 20.4, 24.9, 27.0, 28.3, 30.4, 33.5, 37.3, 39.3, 42.1, 50.2, 61.1, 65.7, 70.5, 75.9, 85.3, 125.1, 129.3, 152.3, 165.5, 170.4, 186.2, 198.9. Anal. calcd for $\mathrm{C}_{23} \mathrm{H}_{27} \mathrm{BrO}_{6}$ : C, 57.63; H, 5.68; Br, 16.67. Found: C, 57.75; H, 5.66; Br, 16.62.

1,4-Pregnadiene-11-hydroxy-16 $\alpha, 17 \alpha$-epoxy-3,20-dione (10). To a boiling and stirring suspension of epoxide $9(0.50 \mathrm{~g}, 1.04$ $\mathrm{mmol})$ in anhydrous THF $(13.0 \mathrm{~mL})$, a solution of $\mathrm{Bu}_{3} \mathrm{SnH}(0.36$ $\mathrm{mL}, 1.25 \mathrm{mmol}$ ) and AIBN (catalytic amount, $33.3 \mathrm{mg}, 0.21$ $\mathrm{mmol})$ in THF $(10 \mathrm{~mL})$ was added dropwise under nitrogen atmosphere. The reaction mixture was stirred for $30 \mathrm{~min}$ at reflux temperature. The crude residue was then concentrated under reduced pressure and recrystallized from AcOEt to give 10 ( $0.41 \mathrm{~g}, 98 \%$ yield). Epoxide 10 (40\% yield) was also obtained from compound $\mathbf{8}$ by epoxidation reaction using the same procedure reported for 9. Data for 10: white solid, ${ }^{1} \mathrm{H}$ NMR (400 $\mathrm{MHz}): \delta$ 1.02-1.14 (m, 2H), 1.39 (s, 3H), 1.46 (s, 3H), 1.46-1.51 (m, 2H), 1.62-1.70 (m, 1H), 1.97-2.02 (m, 3H), 2.15 (s, 3H), 2.15$2.19(\mathrm{~m}, 1 \mathrm{H}), 2.29-2.38(\mathrm{~m}, 1 \mathrm{H}), 2.51-2.62(\mathrm{~m}, 1 \mathrm{H}), 3.82(\mathrm{~s}, 1 \mathrm{H})$, 4.42 (bs, 1H), 4.57 (d, $J=13.4,1 \mathrm{H}), 4.66$ (d, $J=13.4,1 \mathrm{H}), 6.00$ (bs, $1 \mathrm{H}), 6.26(\mathrm{dd}, J=1.8,10.1,1 \mathrm{H}), 7.21(\mathrm{~d}, J=10.1,1 \mathrm{H}) \cdot{ }^{13} \mathrm{C}$ NMR (100 MHz): 17.4, 20.5, 21.3, 27.8, 28.3, 29.5, 31.9, 33.4, 41.0, 42.0, 44.2, 45.1, 56.2, 61.4, 65.8, 69.9, 122.6, 128.0, 156.1, 169.6, 170.4, 186.6, 190.0. Anal. calcd for $\mathrm{C}_{23} \mathrm{H}_{28} \mathrm{O}_{6}$ : C, 68.98; $\mathrm{H}$, 7.05. Found: C, 69.05; H, 7.03.

1,4,17-Pregnatriene-11-hydroxy-3,20-dione (8). Compound 8 was obtained in $93 \%$ yield from 7 by using the same conditions reported above for preparation of $\mathbf{1 0}$. Data for 8: white solid, ${ }^{1} \mathrm{H}$ NMR (500 MHz): $\delta 1.06-1.21(\mathrm{~m}, 1 \mathrm{H}), 1.26(\mathrm{~s}, 3 \mathrm{H}), 1.32-1.38(\mathrm{~m}$, $1 \mathrm{H}), 1.49$ (s, 3H), 1.59-1.63 (m, 2H), 2.06-2.12 (m, 1H), 2.17 (s, $3 \mathrm{H}), 2.18-2.30(\mathrm{~m}, 2 \mathrm{H}), 2.33-2.43(\mathrm{~m}, 2 \mathrm{H}), 2.45-2.51(\mathrm{~m}, 1 \mathrm{H})$, 2.55-2.67 (m, 1H), 4.40 (bs, 1H), 4.85 (d, $J=16.1,1 \mathrm{H}), 5.01$ (d, $J$ $=16.1,1 \mathrm{H}), 6.01(\mathrm{bs}, 1 \mathrm{H}), 6.27$ (d, $J=10.1,1 \mathrm{H}), 6.73(\mathrm{bs}, 1 \mathrm{H})$, $7.31(\mathrm{~d}, J=10.1,1 \mathrm{H}) .{ }^{13} \mathrm{C} \mathrm{NMR}(100 \mathrm{MHz}): 18.4,20.5,21.2,30.1$, 31.8, 32.8, 33.6, 44.2, 44.6, 46.1, 56.1, 56.4, 65.5, 70.2, 122.5, 128.0, 143.5, 152.2, 156.1, 169.4, 170.2, 186.6, 190.5. Anal. calcd for $\mathrm{C}_{23} \mathrm{H}_{28} \mathrm{O}_{5}$ : C, 71.85; H, 7.34. Found: C, 71.80; H, 7.35.

20-Carboethoxyhydrazone of 1,4-pregnadiene-11-hydroxy$16 \alpha, 17 \alpha$-epoxy-3-one (13). To a stirring suspension of $10(0.50 \mathrm{~g}$, $1.25 \mathrm{mmol}$ ) in anhydrous 1,4-dioxane (24 mL), ethyl carbazate $(0.26 \mathrm{~g}, 2.5 \mathrm{mmol})$ and $p$-toluenesulfonic acid $(0.24 \mathrm{~g}, 1.25$ $\mathrm{mmol}$ ) were sequentially added at room temperature under argon atmosphere. The resulting mixture was stirred at the 
same temperature for $8 \mathrm{~h}$. Then aq. $\mathrm{NaHCO}_{3}$ was added and the mixture extracted with EtOAc; the organic layer was dried $\left(\mathrm{Na}_{2} \mathrm{SO}_{4}\right)$ and the solvent evaporated under reduced pressure. The solid residue was recrystallized from $\mathrm{Et}_{2} \mathrm{O}$ to give the final compound 13 (0.36 g, 59\% yield) as a white solid. ${ }^{1} \mathrm{H}$ NMR (500 MHz): $\delta$ 1.01-1.12 (m, 2H), 1.15-1.27 (m, 2H), 1.31 (s, 3H), 1.33 $(\mathrm{t}, J=7.1,3 \mathrm{H}), 1.40-1.44(\mathrm{~m}, 1 \mathrm{H}), 1.47(\mathrm{~s}, 3 \mathrm{H}), 1.68(\mathrm{dd}, J=3.1$, 14.2, 1H), 1.96-2.04 (m, 2H), 2.13 (s, 3H), 2.15-2.18 (m, 1H), 2.32 $(\mathrm{dd}, J=3.0,12.7,1 \mathrm{H}), 2.50-2.61(\mathrm{~m}, 2 \mathrm{H}), 3.67$ (s, 1H), 4.22-4.29 $(\mathrm{m}, 2 \mathrm{H}), 4.31(\mathrm{~d}, J=13.1,1 \mathrm{H}), 4.40(\mathrm{bs}, 1 \mathrm{H}), 4.56(\mathrm{~d}, J=13.1$, $1 \mathrm{H}), 6.00$ (bs, 1H), 6.25 (d, $J=10.1,1 \mathrm{H}), 7.29$ (d, $J=10.1,1 \mathrm{H})$. ${ }^{13}$ C NMR (125 MHz): 14.6, 18.2, 20.6, 21.2, 27.2, 29.9, 31.9, 33.5, 41.4, 41.7, 44.2, 45.9, 55.0, 56.2, 59.6, 62.1, 69.8, 70.2, 122.5, $127.8,142.5,153.6,156.2,169.7,171.2,186.6$. Anal. calcd for $\mathrm{C}_{26} \mathrm{H}_{34} \mathrm{~N}_{2} \mathrm{O}_{7}$ : C, 64.18; H, 7.04; N 5.76. Found: C, 64.29; H, 7.02 ; N 5.75 .

20-Carboethoxyhydrazone of 1,4-pregnadiene-16 $\alpha$-amino11,17 $\alpha$-diol-3-one (16). Method A. Epoxide 13 (0.30 g, $0.62 \mathrm{mmol})$ was dissolved in anhydrous 1,4-dioxane (15 mL) under nitrogen atmosphere at rt. Anhydrous ammonia was then gently bubbled into the solution for 3 minutes and the reaction was stirred at the same temperature for $18 \mathrm{~h}$. Nitrogen was bubbled in the reaction mixture until the ammonia was eliminated from the solution $(\mathrm{pH}=7)$. The mixture was diluted with $\mathrm{CH}_{2} \mathrm{Cl}_{2}$ and the organic layers were washed with brine, dried $\left(\mathrm{Na}_{2} \mathrm{SO}_{4}\right)$ and concentrated under reduced pressure. The solid residue was recrystallized from $\mathrm{Et}_{2} \mathrm{O}$ to give the final compound 16 (0.30 g, $97 \%$ yield) as a white solid. Method B (one-pot procedure). To a stirred suspension of $10(0.50 \mathrm{~g}, 1.25 \mathrm{mmol})$ in anhydrous 1,4dioxane $(24 \mathrm{~mL})$, ethyl carbazate $(0.26 \mathrm{~g}, 2.5 \mathrm{mmol})$ and $p$-toluenesulfonic acid $(0.24 \mathrm{~g}, 1.25 \mathrm{mmol})$ were sequentially added at room temperature under argon atmosphere. The resulting mixture was stirred at the same temperature for $8 \mathrm{~h}$ and then anhydrous ammonia was gently bubbled into the solution for 3 minutes. The reaction mixture was stirred at room temperature for $18 \mathrm{~h}$. The mixture was diluted with $\mathrm{CH}_{2} \mathrm{Cl}_{2}$ and the organic layers washed with brine, dried $\left(\mathrm{Na}_{2} \mathrm{SO}_{4}\right)$ and concentrated under reduced pressure. The solid residue was recrystallized from $\mathrm{Et}_{2} \mathrm{O}$ to give the final compound $16(0.43 \mathrm{~g}, 69 \%$ overall yield). ${ }^{1} \mathrm{H}$ NMR (400 MHz, acetone- $\left.d_{6}\right): \delta$ 1.04-1.16 $(\mathrm{m}, 5 \mathrm{H})$, 1.21-1.41 (m, 4H), 1.51 (s, 3H), 1.52-1.57 (m, 1H), 1.78-1.99 (m, $4 \mathrm{H}), 2.03-2.17(\mathrm{~m}, 7 \mathrm{H}), 2.35(\mathrm{dd}, J=3.4,13.4,1 \mathrm{H}), 2.62(\mathrm{td}, J=$ $4.9,13.4,1 \mathrm{H}), 3.81$ (bs, $1 \mathrm{H}), 4.17$ (q, $J=7.1,2 \mathrm{H}), 4.47$ (bs, $1 \mathrm{H}$ ), $4.76(\mathrm{~d}, J=13.0,1 \mathrm{H}), 4.90(\mathrm{~d}, J=13.0,1 \mathrm{H}), 5.16(\mathrm{dd}, J=3.0,9.2$, $1 \mathrm{H}), 5.92$ (bs, $1 \mathrm{H}), 6.14$ (dd, $J=1.6,10.1,1 \mathrm{H}), 7.33$ (d, $J=10.1$, 1H). ${ }^{13} \mathrm{C}$ NMR (100 MHz, acetone- $\left.d_{6}\right): 14.0,18.2,19.9,20.8,29.7$, 30.9, 31.6, 33.9, 40.9, 44.0, 46.4, 48.9, 55.6, 58.2, 60.8, 69.4, 81.2, 83.7, 121.8, 127.3, 149.4, 153.6, 155.9, 170.1, 170.3, 185.1. Anal. calcd for $\mathrm{C}_{26} \mathrm{H}_{37} \mathrm{~N}_{3} \mathrm{O}_{7}$ : C, 62.01; $\mathrm{H}, 7.41 ; \mathrm{N}$ 8.34. Found: C, 62.08; $\mathrm{H}, 7.38$; $\mathrm{N} 8.36$.

20-Carboethoxyhydrazone of 1,4-pregnadiene-11-hydroxy$16 \alpha, 17 \alpha$-oxazole-3-one (17). $\mathrm{I}_{2}(0.30 \mathrm{~g}, 1.19 \mathrm{mmol})$ was added to a stirred solution of polymer supported triphenylphosphine (PS-TPP; 100-200 mesh, extent of labeling: $\sim 3 \mathrm{mmol} \mathrm{g}^{-1}$ triphenylphosphine loading) (0.40 g, $1.19 \mathrm{mmol})$ in anhydrous DCM $(20 \mathrm{~mL})$ at rt. Then glacial acetic acid $(35 \mu \mathrm{L}, 0.59 \mathrm{mmol})$ was added and the solution was stirred at room temperature for $20^{\prime}$. Afterwards, $16(0.30 \mathrm{~g}, 0.59 \mathrm{mmol})$ and imidazole $(0.16 \mathrm{~g}$, $2.38 \mathrm{mmol}$ ) were sequentially added and the solution was warmed to $40{ }^{\circ} \mathrm{C}$ and stirred for $2 \mathrm{~h}$. The mixture was then filtered and the solvent removed under reduced pressure. The solid residue was recrystallized from $\mathrm{Et}_{2} \mathrm{O}$ to give the final compound 17 (0.29 g, 96\% yield) as a white solid. ${ }^{1} \mathrm{H}$ NMR (500 MHz, acetone- $\left.d_{6}\right): \delta 1.04(\mathrm{dd}, J=3.7,11.4,1 \mathrm{H}), 1.07(\mathrm{~s}, 1 \mathrm{H})$, 1.09-1.18 (m, 1H), $1.27(\mathrm{t}, J=7.1,1 \mathrm{H}), 1.29-1.36(\mathrm{~m}, 3 \mathrm{H}), 1.51(\mathrm{~s}$, $3 \mathrm{H}), 1.74(\mathrm{dd}, J=5.7,13.6,1 \mathrm{H}), 1.81(\mathrm{dd}, J=7.6,13.6,1 \mathrm{H}), 1.85-$ $1.90(\mathrm{~m}, 4 \mathrm{H}), 2.12(\mathrm{~s}, 3 \mathrm{H}), 2.18-2.25(\mathrm{~m}, 1 \mathrm{H}), 2.35(\mathrm{dd}, J=3.4$, $13.5,1 \mathrm{H}), 2.65(\mathrm{td}, J=5.7,13.5,1 \mathrm{H}), 3.83(\mathrm{bs}, 1 \mathrm{H}), 4.17$ (q, $J=$ 7.1, 2H), 4.47 (bs, $1 \mathrm{H}), 4.73(\mathrm{~d}, J=13.0,1 \mathrm{H}), 4.92(\mathrm{~d}, J=13.0$, $1 \mathrm{H}), 5.66(\mathrm{~d}, J=5.7,1 \mathrm{H}), 5.92(\mathrm{bs}, 1 \mathrm{H}), 6.14(\mathrm{dd}, J=1.8,10.1$, $1 \mathrm{H}), 7.31$ (d, $J=10.1,1 \mathrm{H}), 9.37$ (bs, $1 \mathrm{H}) .{ }^{13} \mathrm{C}$ NMR $(125 \mathrm{MHz}$, acetone- $\left.d_{6}\right): 13.2,14.0,19.1,19.9,20.8,29.7,30.6,31.5,33.9$, 41.7, 43.9, 47.0, 50.4, 55.5, 57.5, 60.9, 69.1, 83.7, 91.6, 121.9, 127.4, 145.9, 153.4, 155.7, 165.1, 169.5, 170.2, 185.0. Anal. calcd for $\mathrm{C}_{28} \mathrm{H}_{37} \mathrm{~N}_{3} \mathrm{O}_{7}$ : C, 63.74; $\mathrm{H}, 7.07 ; \mathrm{N}$ 7.96. Found: C, 63.81; $\mathrm{H}$, 7.02; N 7.99.

Deflazacort (5). To a stirred solution of 17 (0.30 g, $0.57 \mathrm{mmol})$ in acetone $(8 \mathrm{~mL}), \mathrm{HCl} 37 \%$ solution $(0.09 \mathrm{~mL}, 1.14 \mathrm{mmol})$ was added and stirring at room temperature for $24 \mathrm{~h}$. Then aq. $\mathrm{NaHCO}_{3}$ was added and the mixture extracted with $\mathrm{CH}_{2} \mathrm{Cl}_{2}$; the combined organic layers were washed with brine, dried $\left(\mathrm{Na}_{2} \mathrm{SO}_{4}\right)$ and the solvent evaporated under reduced pressure. Chromatography of the crude residue over silica gel (hexane $:$ acetone $=7: 3)$ gave the pure DFZ (5) ( $0.18 \mathrm{~g}, 72 \%$ yield) as a white solid. ${ }^{1} \mathrm{H}$ NMR (400 MHz, $\left.\mathrm{CD}_{3} \mathrm{OD}\right): \delta 1.01$ (dd, $J=3.6$, 11.3, 1H), 1.02 (s, 3H), 1.06-1.25 (m, 2H), 1.49 (s, 3H), 1.75 (dd, J $=5.9,13.8,1 \mathrm{H}), 1.79-1.85(\mathrm{~m}, 1 \mathrm{H}), 1.89(\mathrm{dd}, J=3.9,14.2,1 \mathrm{H})$, 1.97 (s, 3H), 2.01 (dd, $J=2.7,13.8,1 \mathrm{H}), 2.06-2.12(\mathrm{~m}, 1 \mathrm{H}), 2.13$ (s, 3H), $2.20(\mathrm{dd}, J=4.1,11.6,1 \mathrm{H}), 2.37$ (ddd, $J=1.8,4.6,13.4$, $1 \mathrm{H}), 2.65(\mathrm{td}, J=5.7,13.4,1 \mathrm{H}), 4.41(\mathrm{dd}, J=3.2,6.3,1 \mathrm{H}), 4.93(\mathrm{~s}$, $2 \mathrm{H}), 5.30(\mathrm{~d}, J=5.5,1 \mathrm{H}), 6.00(\mathrm{bs}, 1 \mathrm{H}), 6.25$ (dd, $J=1.9,10.1$, $1 \mathrm{H}), 7.45$ (d, $J=10.1,1 \mathrm{H}) .{ }^{13} \mathrm{C}$ NMR (125 MHz, $\left.\mathrm{CD}_{3} \mathrm{OD}\right): 12.5$, 17.2, 18.9, 20.1, 30.4, 31.6, 33.9, 34.0, 40.9, 44.5, 50.4, 55.5, 67.0, 69.0, 84.8, 94.2, 121.2, 126.5, 158.3, 168.0, 170.6, 172.8, 187.5, 200.9. Anal. calcd for $\mathrm{C}_{25} \mathrm{H}_{31} \mathrm{NO}_{6}$ : C, 68.01; H, 7.08; N 3.17. Found: C, 68.09; H, 7.06; N 3.15.

\section{Biology}

Antimicrobial activity. Acinetobacter baumannii ATCC 17978 and Staphylococcus aureus ATCC 29213, well-known as not resistant strains, were evaluated as a Gram-negative and Grampositive model and were obtained from the American Type Culture Collection. Both strains were grown on blood agar plates (TSA), as described previously. ${ }^{18}$ Minimum inhibitory concentration (MIC) values of steroidal compounds against planktonic bacteria were examined by a broth microdilution method previously described. ${ }^{20}$ Briefly, compounds were dissolved in dimethyl sulfoxide (DMSO) to obtain a concentration of $50 \mathrm{mg} \mathrm{mL} \mathrm{m}^{-1}$. Two-fold serial dilutions ranging from $1 \mathrm{mg}$ $\mathrm{mL}^{-1}$ to $2 \mu \mathrm{g} \mathrm{mL}{ }^{-1}$ of the compounds were prepared in triplicate and placed into a polystyrene 96-well plate. Bacterial cell suspensions were prepared at an equivalent to a 0.5 McFarland standard and were subsequently diluted in cation-adjusted 
Mueller-Hinton broth so that the final culture density was equal to $5 \times 106$ colony forming unit (cfu) per $\mathrm{mL} 100 \mu \mathrm{L}$ of bacteria ( 5 $\times 105 \mathrm{cfu}$ ) were then added to the microtiter plates containing steroidal compounds. One well with no antibiotic was used as a positive growth control on each plate. The plates were incubated at $37^{\circ} \mathrm{C}$ for $18-24 \mathrm{~h}$ under shaking (300 rpm) and the MIC was calculated on the basis of concentration of compound in the well having no visible growth. To evaluate the effect of DMSO on bacteria growth kinetics, separate DMSO controls were used. To calculate the minimum bactericidal concentration (MBC), bacterial suspensions from MIC assay microtiter wells were diluted in PBS and spot-plated on TSA plates to count colonies after incubation at $37{ }^{\circ} \mathrm{C}$ for $18 \mathrm{~h}$. The $\mathrm{MBC}$ was determined as the lowest concentration of substance, which produced $\geq 99.9 \%$ killing ( $\geq 3 \log 10$ ) after $24 \mathrm{~h}$ of incubation as compared to the colony count of the starting inoculum. All tests were performed in triplicate and repeated three times.

Hemolysis assay. Cytotoxicity was determined spectrophotometrically by measuring the haemoglobin release from horse erythrocytes. ${ }^{21}$ Briefly, fresh defibrinated horse blood (Oxoid) was centrifuged at $500 \times g$ for $5 \mathrm{~min}$ and then washed three times with PBS, pH 7.4. Red blood cells were diluted to $4 \%$ in PBS and $190 \mu \mathrm{L}$ were added to $10 \mu \mathrm{L}$ of 10 (ranging from $512 \mu \mathrm{g}$ $\mathrm{mL}^{-1}$ to $1 \mathrm{mg} \mathrm{mL}^{-1}$ ) in a 96-well plate. After $1 \mathrm{~h}$ of incubation at $37{ }^{\circ} \mathrm{C}$, the suspensions were centrifuged for $5 \mathrm{~min}$ at $500 \times \mathrm{g}$. Then, $150 \mu \mathrm{L}$ of the supernatant was transferred to a new 96well plate to measure the absorbance at $450 \mathrm{~nm}$ by using a microplate reader, and the percentage of hemolysis was calculated. As a positive control for hemolysis (100\% lysis), 1\% (v/v) Triton X-100 solution was used. PBS with DMSO (ranging from 1 to $0.0039 \%$ ) was used as a negative control (0\% lysis). Assays were performed in triplicates and repeated twice.

\section{Conflicts of interest}

There are no conflicts to declare.

\section{Acknowledgements}

AG and AE wish to thank Dr Mario Micciarelli and Prof. Giovanni Palumbo for valuable suggestions and helpful discussions regarding various aspects of this project.

\section{Notes and references}

1 S. Samuel, T. Nguyen and H. A. Choi, J. Neurocrit. Care, 2017, 10, 53.

2 S. Gessi, S. Merighi and P. A. Borea, Curr. Pharm. Des., 2010, 16, 3540 .

3 G. Nathansohn, G. Winters and E. Testa, J. Med. Chem., 1967, 10, 799.

4 A. Markham and H. M. Bryson, Drugs, 1995, 50, 317.

5 L. Parente, BMC Pharmacol. Toxicol., 2017, 18, 1.

6 A. Assandri, G. Buniva, E. Martinelli, A. Perazzi and L. Zerilli, Adv. Exp. Med. Biol., 1984, 171, 9.
7 H. Coirini, D. Flores, M. C. Vega, M. C. Gonzalez Deniselle and A. F. De Nicola, J. Steroid Biochem. Mol. Biol., 1994, 49, 43.

8 (a) K. Traynor, Am. J. Health Syst. Pharm., 2017, 74, 368; (b) W. D. Biggar, L. Politano, V. A. Harris, L. Passamano, J. Vajsar, B. Alman, A. Palladino, L. I. Comi and G. Nigro, Neuromuscul. Disord., 2004, 14, 476.

9 (a) D. D'Alonzo, M. De Fenza, C. Porto, R. Iacono, M. Huebecker, B. Cobucci-Ponzano, D. A. Priestman, F. Platt, G. Parenti, M. Moracci, G. Palumbo and A. Guaragna, J. Med. Chem., 2017, 60, 946; (b) R. Caputo, U. Ciriello, P. Festa, A. Guaragna, G. Palumbo and S. Pedatella, Eur. J. Org. Chem., 2003, 14, 2617; (c) M. F. Caso, D. D'Alonzo, S. D'Errico, G. Palumbo and A. Guaragna, Org. Lett., 2015, 17, 2626; (d) R. Caputo, A. Guaragna and G. Palumbo, Eur. J. Org. Chem., 1999, 6, 1455.

10 See for example: P. Jia, X. Wu, Y. Yu and G. Zhang, Steroids, 2009, 74, 229.

11 R. Jouve, V. Thery, S. Ducki, J. Helfenbein, J.-C. Thiery, A. Job, El. Picard, C. Mallet, I. Ripoche and K. Bennis, Steroids, 2018, 137, 14.

12 See for example: X. Runxing, CN Pat., 108484714A, 2018; D. Lianqiang, and L. Mingqing, CN Pat., 106397532A, 2017.

13 H. Yao and D. E. Richardson, J. Am. Chem. Soc., 2000, 122, 3220.

14 A. V. Kamernitskii and A. M. Turuta, Pharm. Chem. J., 1992, 26, 526.

15 D. H. Drewry, D. M. Coe and S. Poon, Med. Res. Rev., 1999, 19, 97.

16 (a) M. De Fenza, D. D'Alonzo, A. Esposito, S. Munari, N. Loberto, A. Santangelo, I. Lampronti, A. Tamanini, A. Rossi, S. Ranucci, I. De Fino, A. Bragonzi, M. Aureli, M. Tironi, G. Lippi, R. Gambari, G. Cabrini, G. Palumbo, M. C. Dechecchi and A. Guaragna, Eur. J. Med. Chem., 2019, 175, 63; (b) R. Caputo, G. Cecere, A. Guaragna, G. Palumbo and S. Pedatella, Eur. J. Org. Chem., 2002, 17, 3050; (c) S. Pedatella, A. Guaragna, D. D'Alonzo, M. De Nisco and G. Palumbo, Synthesis, 2006, 2, 305.

17 S. L. Regen and D. P. Lee, J. Org. Chem., 1975, 40, 1669.

18 E. De Gregorio, E. Roscetto, V. D. Iula, M. Martinucci, R. Zarrilli, P. P. Di Nocera and M. R. Catania, New Microbiol., 2015, 38, 251.

19 E. Tacconelli, E. Carrara, A. Savoldi, S. Harbarth, M. Mendelson, D. L. Monnet, C. Pulcini, G. Kahlmeter, J. Kluytmans, Y. Carmeli, M. Ouellette, K. Outterson, J. Patel, M. Cavaleri, E. M. Cox, C. R. Houchens, M. L. Grayson, P. Hansen, N. Singh, U. Theuretzbacher and N. Magrini, Lancet Infect. Dis., 2018, 18, 318.

20 K. Pane, V. Cafaro, A. Avitabile, M. T. Torres, A. Vollaro, E. De Gregorio, M. R. Catania, A. Di Maro, A. Bosso, G. Gallo, A. Zanfardino, M. Varcamonti, E. Pizzo, A. Di Donato, T. K. Lu, C. de la Fuente-Nunez and E. Notomista, ACS Synth. Biol., 2018, 7, 2105.

21 A. Ebbensgaard, H. Mordhorst, M. T. Overgaard, F. M. Aarestrup and E. B. Hansen, PLoS One, 2018, 13(5), e0197742. 